\title{
Visualizing the three-step freezing process and three-phase reaction not predicted by the (NH4) 2504/H2O phase diagram
}

\author{
Anatoli Bogdan \\ Department of Chemistry, University of Helsinki, P.O. Box 55, FI-00014 Helsinki, Finland \\ Institute for Atmospheric and Earth System Research/Physics, Faculty of Science, University of Helsinki, P.O. Box 64, Hel- \\ sinki 00014, Finland
}

KEYWORDS: $\left(\mathrm{NH}_{4}\right)_{2} \mathrm{SO}_{4} / \mathrm{H}_{2} \mathrm{O}$ phase diagram, Supercooling, Three-step freezing, Freeze-induced phase separation (FIPS), Freeze-concentrated solution (FCS), Three-phase reaction, DSC, Optical cryo-microscopy

\begin{abstract}
According to the conventional phase diagrams, aqueous solutions freeze at the liquidus and are frozen/solid below the eutectic solidus. Herein, using differential scanning calorimetry (DSC) and optical cryo-microscopy (OC-M), we demonstrate that hypoeutectic, eutectic $40 \mathrm{wt} \%\left(\mathrm{NH}_{4}\right)_{2} \mathrm{SO}_{4}$ and hypereutectic $\left(\mathrm{NH}_{4}\right)_{2} \mathrm{SO}_{4} / \mathrm{H}_{2} \mathrm{O}$ remain liquid well below the eutectic solidus before freezing in three steps: fast-slow-fast. The first fast freezing produces a ramified ice microstructure (IM) and freeze-concentrated solution (FCS) containing up to $\sim 70 \mathrm{wt} \%\left(\mathrm{NH}_{4}\right)_{2} \mathrm{SO}_{4}$. As temperature decreases further, the slow freezing of FCS precedes its fast freezing, which produces a striped IM and $\left(\mathrm{NH}_{4}\right)_{2} \mathrm{SO}_{4}$ microcrystals. Videos recorded upon warming of frozen $\left(\mathrm{NH}_{4}\right)_{2} \mathrm{SO}_{4} / \mathrm{H}_{2} \mathrm{O}$ reveal a new three-phase reaction, which is the recrystallization of ice and $\left(\mathrm{NH}_{4}\right)_{2} \mathrm{SO}_{4}$ microcrystals into the lamellar eutectic ice- $\left(\mathrm{NH}_{4}\right)_{2} \mathrm{SO}_{4}$ superlattice. This work demonstrates limitations of the $\left(\mathrm{NH}_{4}\right)_{2} \mathrm{SO}_{4} / \mathrm{H}_{2} \mathrm{O}$ phase diagram and proposes an effective strategy for studying other deeply supercooled solutions whose behavior is not predicted by the phase diagram.
\end{abstract}

Understanding the freezing process is important for life sciences, ${ }^{1-3}$ nanochemistry, ${ }^{4,5}$ different natural, ${ }^{6-10}$ biotechnologi$\mathrm{cal}^{11-17}$ and industrial ${ }^{18-20}$ processes. Common to all these scopes is a freeze-induced phase separation (FIPS) into ice and a freeze-concentrated solution (FCS). ${ }^{10,12,21-24}$ IM/FCS morphology and the phase state of FCS determine the properties of frozen solutions ${ }^{12,25-27}$ and, consequently, the properties of freezedried/lyophilized products, ${ }^{11-15}$ glaciers, ${ }^{8,28}$ sea ice, ${ }^{9,29}$ ice clouds ${ }^{10}$ etc. Unlike bulk solutions, which freeze at the liquidus ${ }^{30-33}$ millimeter-scaled drops can be supercooled below the eutectic solidus. ${ }^{34}$ Depending on solute molecular structure, several freezing ${ }^{6,10,34,35}$ and glass transition ${ }^{12,35}$ events occur upon cooling. The number of freezing and melting events depends on solution size. ${ }^{35-37}$ Freezing and accompanying FIPS resume upon warming of glassy FCS. ${ }^{12,35}$ These results differ from the predictions of phase diagrams and show that further study of deeply supercooled solutions are necessary.

In this work, we employ DSC for the study of deeply supercooled eutectic and hypereutectic $\left(\mathrm{NH}_{4}\right)_{2} \mathrm{SO}_{4} / \mathrm{H}_{2} \mathrm{O}$ and OC-M for visualization of the phase transitions of deeply supercooled hypoeutectic, eutectic and hypereutectic $\left(\mathrm{NH}_{4}\right)_{2} \mathrm{SO}_{4} / \mathrm{H}_{2} \mathrm{O}$. Ammonium sulfate, $\left(\mathrm{NH}_{4}\right)_{2} \mathrm{SO}_{4}$, has practical implications ${ }^{38}$ and plays an essential role in the atmosphere. ${ }^{39,40}$ Details of the DSC and OC-M experiments are reported elsewhere. ${ }^{10,12,34-37}$

DSC measurements: In Figure 1a, the cooling thermograms of millimeter-scaled drops contain two exothermic peaks $\mathrm{T}_{\mathrm{f} \text {,ice }}$ and $\mathrm{T}_{\mathrm{f}, \mathrm{FCS}}$. Warming thermograms contain one broad endothermic peak that begins at the eutectic temperature $\mathrm{T}_{\mathrm{E}}=254 \mathrm{~K}$. In Figure 1b, magnified thermograms reveal an inclined thermogram between $\mathrm{T}_{\mathrm{f} \text {,ice }}$ and $\mathrm{T}_{\mathrm{f}, \mathrm{FCS}}$. The para-to-ferroelectric and ferro-to-paraelectric transitions at $\mathrm{T}_{\mathrm{c}}=223.5 \mathrm{~K}$ indicate that $\left(\mathrm{NH}_{4}\right)_{2} \mathrm{SO}_{4}$ crystals form at $\mathrm{T}_{\mathrm{f}, \mathrm{FCS}}$. Thermograms of emulsified micrometer-scaled drops contain only peaks $\mathrm{T}_{\mathrm{f}, \mu \mathrm{m}}$ and $\mathrm{T}_{\mathrm{E}}$ (Figure 1c).

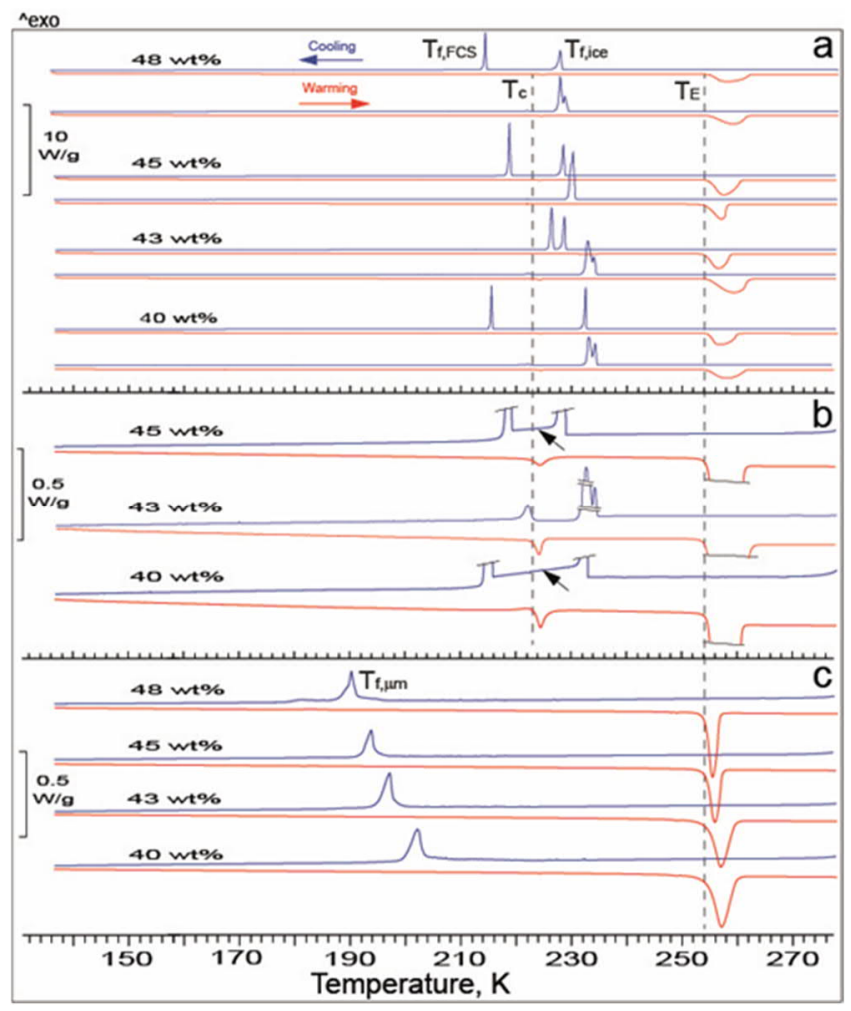

Figure 1. DSC thermograms of eutectic and hypereutectic $\left(\mathrm{NH}_{4}\right)_{2} \mathrm{SO}_{4} / \mathrm{H}_{2} \mathrm{O}$. a, Thermograms of millimeter-scaled drops. Peaks $\mathrm{T}_{\mathrm{f} \text {,ice }}$ and $\mathrm{T}_{\mathrm{f}, \mathrm{FCS}}$ are due to ice crystallization and the fast freezing of FCS, respectively. $\mathrm{T}_{\mathrm{E}}$ denotes the eutectic melting. b, The 20-fold magnification of thermograms from Figure 1a. Transition peaks are reduced to fit the figure. Arrows mark inclined thermograms of the slow freezing of FCS. $T_{c}$ is the Curie temperature. c, Thermograms of emulsified micrometer-scaled drops. $\mathrm{T}_{\mathrm{f}, \mu \mathrm{m}}$ is a 
freezing temperature. Heat flow scale bar $(\mathrm{W} / \mathrm{g})$ and concentration $(\mathrm{wt} \%)$ are indicated.

The cooling thermograms in Figure 1 are similar to those of hypoeutectic millimeter-scaled and micrometer-scaled $\left(\mathrm{NH}_{4}\right)_{2} \mathrm{SO}_{4} / \mathrm{H}_{2} \mathrm{O}$ drops. ${ }^{34,36,37,41}$ Hypoeutectic $\mathrm{T}_{\mathrm{f}, \text { ice, }}, \mathrm{T}_{\mathrm{f}, \mathrm{FCS}}$ and the inclined thermogram between them were related to ice crystallization, the fast freezing of FCS and slow freezing of FCS. However, in Figure 1b, the nature of $\mathrm{T}_{\mathrm{f}, \mathrm{ice}}, \mathrm{T}_{\mathrm{f}, \mathrm{FCS}}$ and the inclined thermogram is unclear, because according to the $\left(\mathrm{NH}_{4}\right)_{2} \mathrm{SO}_{4} / \mathrm{H}_{2} \mathrm{O}$ phase diagram, ${ }^{42}$ the eutectic solution produces the eutectic ice/ $\left(\mathrm{NH}_{4}\right)_{2} \mathrm{SO}_{4}$ mixture and hypereutectic solutions produce $\left(\mathrm{NH}_{4}\right)_{2} \mathrm{SO}_{4}$ crystals and the eutectic ice/ $\left(\mathrm{NH}_{4}\right)_{2} \mathrm{SO}_{4}$ mixture (Figure 2).

Unlike the warming thermograms in Figure 1, the warming thermograms of hypoeutectic millimeter-scaled drops contain the eutectic melting $\mathrm{T}_{\mathrm{E}}$ and ice melting $\mathrm{T}_{\mathrm{m}},{ }^{34,36,41}$ and micrometer-scaled drops contain one $\mathrm{e}^{36}$ or two ${ }^{37}$ eutectic melting events and ice melting.

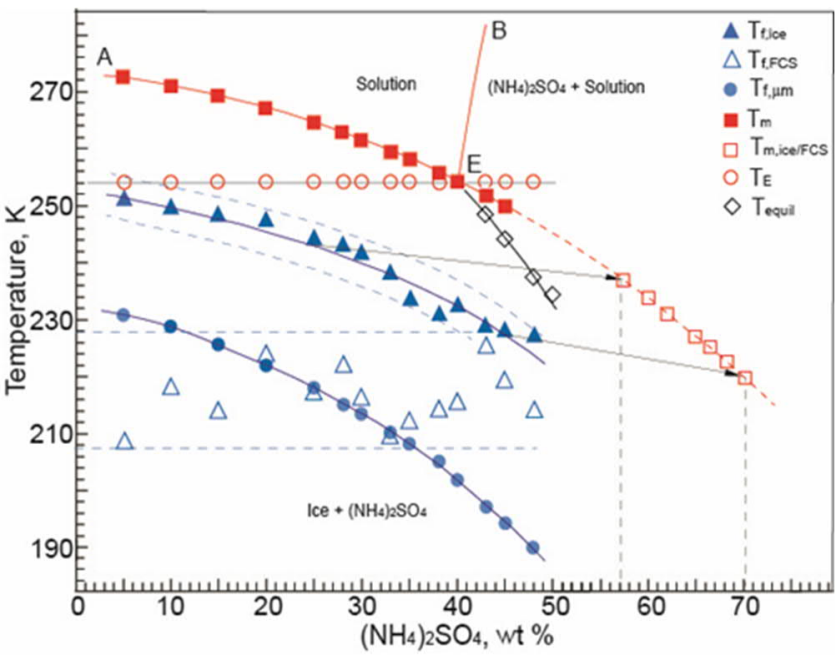

Figure 2. Extended $\left(\mathrm{NH}_{4}\right)_{2} \mathrm{SO}_{4} / \mathrm{H}_{2} \mathrm{O}$ phase diagram. AE and $\mathbf{E B}$ are the liquidus and solubility line of the $\left(\mathrm{NH}_{4}\right)_{2} \mathrm{SO}_{4} / \mathrm{H}_{2} \mathrm{O}$ phase diagram. ${ }^{42}$ Freezing $T_{f, i c e}, T_{f, F C S}, T_{f, \mu m}$ and melting $T_{m}, T_{E}, T_{m, i c e / F C S}$ data points are from this work and refs.36 and 37 (see text and SI). Blue dashed lines mark temperature regions in which $\mathrm{T}_{\text {f,ice }}$ and $\mathrm{T}_{\mathrm{f}, \mathrm{FCS}}$ were detected in our DSC experiments. Arrows show the change of concentration during ice crystallization. $\mathrm{T}_{\text {equil }}$ is taken from ref.43 for comparison. $\mathrm{T}_{\text {equil }}$ was measured when a levitated millimeter-scaled $\left(\mathrm{NH}_{4}\right)_{2} \mathrm{SO}_{4} / \mathrm{H}_{2} \mathrm{O}$ drop was in equilibrium with ice on chamber walls. ${ }^{43}$

To identify the nature of $\mathrm{T}_{\mathrm{f} \text {,ice }}, \mathrm{T}_{\mathrm{f}, \mathrm{FCS}}$ and the inclined thermogram in Figure 1b, we performed truncated measurements in which $25-45 \mathrm{wt} \%\left(\mathrm{NH}_{4}\right)_{2} \mathrm{SO}_{4}$ drops were cooled to temperature above $\mathrm{T}_{\mathrm{f}, \mathrm{FCS}}{ }^{34}$ The obtained thermograms contain an exothermic peak and prolonged endothermic peak (Figure 3a). The latter is due to the melting of ice that is in contact with a highlyconcentrated FCS. ${ }^{12,34,35}$ Supplementary Video 1 (SV1) demonstrates such prolonged ice melting. SV1 shows that ice starts melting at $\sim 235 \mathrm{~K} \ll \mathrm{T}_{\mathrm{E}}=254 \mathrm{~K}$, indicating that the concentration of FCS is much higher than the eutectic $40 \mathrm{wt} \%\left(\mathrm{NH}_{4}\right)_{2} \mathrm{SO}_{4}$ (SI). The FCS concentration is not constant, but increases with the concentration of initial solution and can reach $\sim 70 \mathrm{wt} \%$ $\left(\mathrm{NH}_{4}\right)_{2} \mathrm{SO}_{4}$. Further, all $\mathrm{T}_{\mathrm{m}}$ 's from Figure $3 \mathbf{a}$ exactly meet the equilibrium ice melting $\mathrm{T}_{\mathrm{m}}$-line and its extrapolation below $\mathrm{T}_{\mathrm{E}}$ (Figure 2). This indicates that in Figure $3 \mathbf{a}$ and, consequently, in Figure $1 \mathbf{b}, \mathrm{T}_{\mathrm{f}, \text { ice }}$ is due to ice crystallization. It follows from this that $\mathrm{T}_{\mathrm{f}, \mathrm{FCS}}$ and the inclined thermogram also have the same nature as those of hypoeutectic $\left(\mathrm{NH}_{4}\right)_{2} \mathrm{SO}_{4} / \mathrm{H}_{2} \mathrm{O}$. Videos presented below confirm these unexpected results.

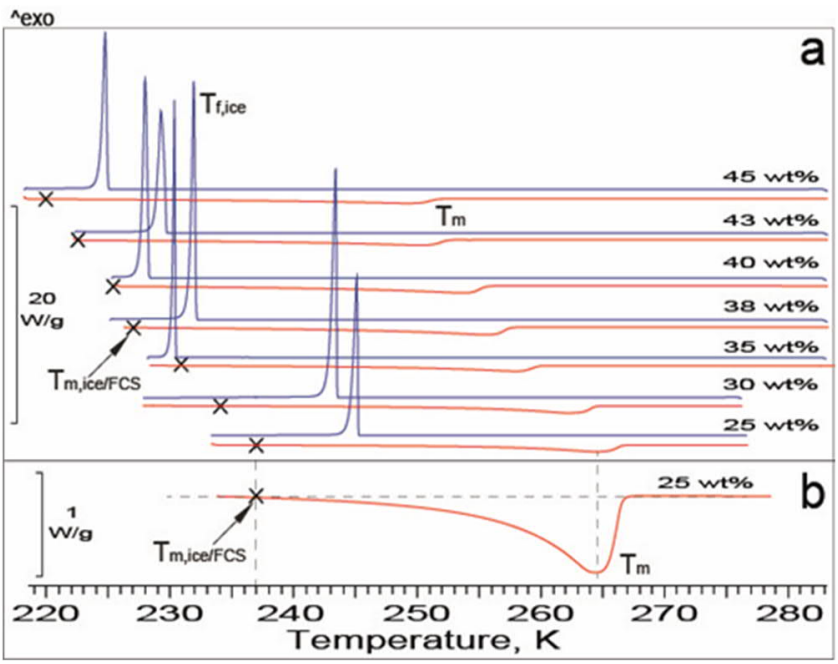

Figure 3. The truncated thermograms of $25-45 \mathrm{wt} \%\left(\mathrm{NH}_{4}\right)_{2} \mathrm{SO}_{4}$ a, A sharp peak $\mathrm{T}_{\mathrm{f} \text {,ice }}$ and prolonged peak $\mathrm{T}_{\mathrm{m}}$ are due to the crystallization and melting of ice, respectively. Crosses mark temperatures $\mathrm{T}_{\mathrm{m}, \mathrm{ice} / \mathrm{FCS}}$ at which the ice in contact with FCS starts melting (see SI). b, The 20-fold magnification of warming $25 \mathrm{wt} \%$ $\left(\mathrm{NH}_{4}\right)_{2} \mathrm{SO}_{4}$ thermogram shows how $\mathrm{T}_{\mathrm{m}, \mathrm{ice} / \mathrm{FCS}}$ is determined.

OC-M measurements: SV2-SV8 demonstrate freezing events $\mathrm{T}_{\mathrm{f}, \text { ice }}$ and $\mathrm{T}_{\mathrm{f}, \mathrm{FCS}}$ that occur in a millimeter-scale drop and films $\sim 10$ - 15 microns thick. ${ }^{10,12}$ Since SV3-SV8 are more informative than SV2, below we will consider only videos recorded from $\left(\mathrm{NH}_{4}\right)_{2} \mathrm{SO}_{4} / \mathrm{H}_{2} \mathrm{O}$ films.

SV3-SV5 of hypoeutectic, eutectic and hypereutectic films without $\left(\mathrm{NH}_{4}\right)_{2} \mathrm{SO}_{4}$ crystals demonstrate separated events $\mathrm{T}_{\mathrm{f} \text {,ice }}$ and $\mathrm{T}_{\mathrm{f}, \mathrm{FCS}}$, which manifest themselves as moving $\mathrm{T}_{\mathrm{f} \text {,ice }}$-front and $\mathrm{T}_{\mathrm{f}, \mathrm{FCS}}$-front. The $\mathrm{T}_{\mathrm{f}, \mathrm{FCS}}$-front pushes unfrozen FCS to the edge of film and forms bulges, which freeze last. SV6-SV8 show that in the films with $\left(\mathrm{NH}_{4}\right)_{2} \mathrm{SO}_{4}$ crystals, $\mathrm{T}_{\mathrm{f} \text {,ice }}$-front and $\mathrm{T}_{\mathrm{f}, \mathrm{FCS}}$-front propagate rapidly one after the other. This indicates that $\left(\mathrm{NH}_{4}\right)_{2} \mathrm{SO}_{4}$ crystals promote the fast freezing $\mathrm{T}_{\mathrm{f}, \mathrm{FCS}}$. SV6-SV8 also demonstrate that $\left(\mathrm{NH}_{4}\right)_{2} \mathrm{SO}_{4}$ crystallizes much slower than ice.

Images $4 \mathbf{a}$ and $4 \mathbf{b}$ show that $\left(\mathrm{NH}_{4}\right)_{2} \mathrm{SO}_{4}$ crystals are yellow in a transmitted light mode and dark green in reflected light mode (arrows 1 and 2). The frozen FCS bulges and channels (arrows 3 and 4) have the same color, indicating that they contain crystalline $\left(\mathrm{NH}_{4}\right)_{2} \mathrm{SO}_{4}$. Image $4 \mathbf{c}$ shows the IM/FCS morphology of completely frozen solution. The frozen FCS looks like a population of isolated channels and pockets. In fact, they are interconnected because $\mathrm{T}_{\mathrm{f}, \mathrm{FCS}}$-front is always even and propagates evenly (image 4d and SV3-SV8). The different brightness of images $4 \mathbf{d}-4 \mathbf{f}$ is due to the non-uniform IM/FCS morphology. Dark strips are rich with ice. Image $4 \mathbf{g}$ shows that ice nucleation is a pointwise event.

In SV9, the moving $\mathrm{T}_{\mathrm{f}, \mathrm{ice}}$-front forms FCS bulges. Unlike the FCS bulges formed by $\mathrm{T}_{\mathrm{f}, \mathrm{FCS}}$-front (SV3-SV5), which freeze immediately after formation, these bulges remain liquid. As temperature decreases further, they grow due to the slow freezing of FCS, which is due to the diffusion of $\mathrm{H}_{2} \mathrm{O}$ from the FCS to IM. Since the specific volume of ice is larger than that of water, the growing IM squeezes FCS channels (image 4c) and this leads to the growth of FCS bulges. 


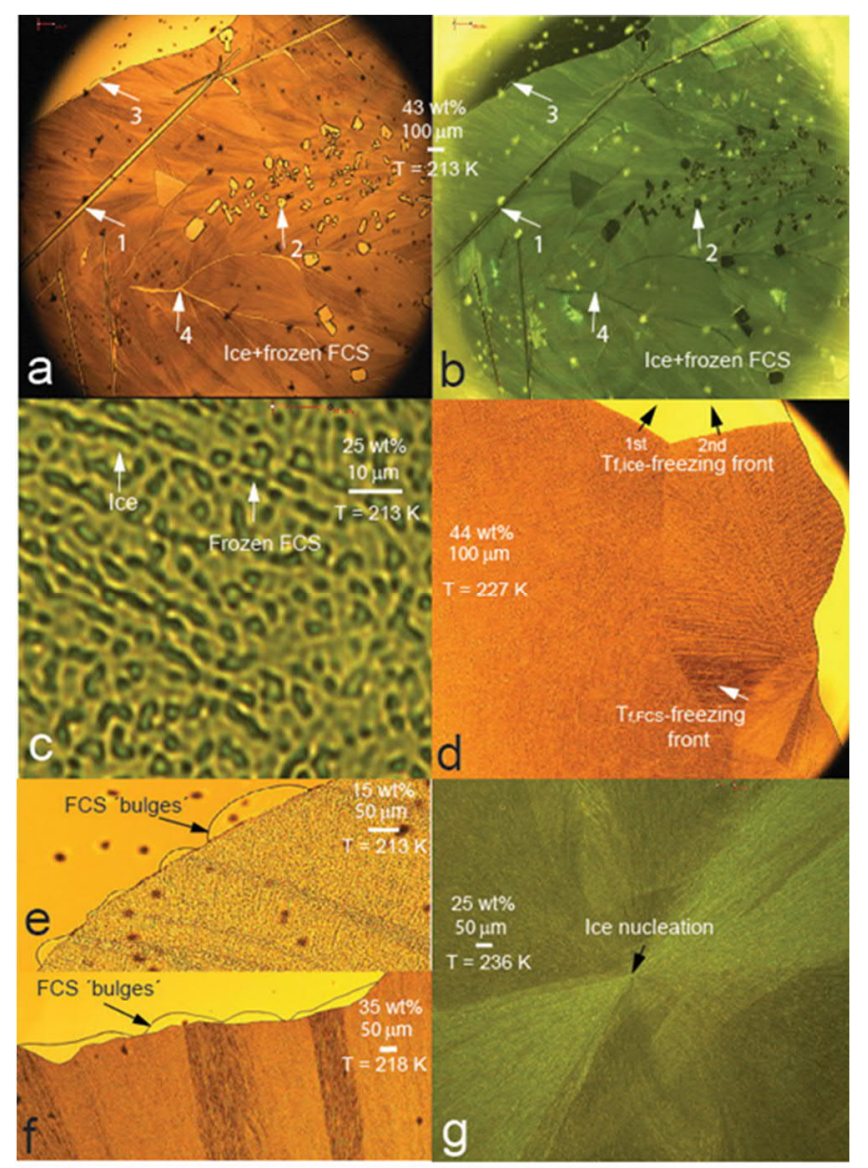

Figure 4. Images of frozen $\left(\mathrm{NH}_{4}\right)_{2} \mathrm{SO}_{4} / \mathrm{H}_{2} \mathrm{O}$ films. Images a, d, $\mathbf{e}$, and $\mathbf{f}$ are taken in a transmitted light mode and images $\mathbf{b}, \mathbf{c}$ and $\mathbf{g}$ in reflected light mode. a, b, Images are taken from the same region. Arrows 1-4 mark long and small $\left(\mathrm{NH}_{4}\right)_{2} \mathrm{SO}_{4}$ crystals, a FCS bulge and FCS channel, respectively. Dark/bright spots are ice crystals formed by vapor deposition on a cover glass. c, IM/FCS morphology under a high magnification. d, A snapshot of two $\mathrm{T}_{\mathrm{f}, \mathrm{ce}}-$ fronts and one $\mathrm{T}_{\mathrm{f}, \mathrm{FCS}}$-front taken from SV5. e, f, Frozen FCS bulges and non-uniform IM/FCS morphology. g, The spot of ice nucleation. Concentration, scale and temperature are indicated.

Unlike the fast freezing $\mathrm{T}_{\mathrm{f}, \text { ice }}$ and the slow freezing of FCS, the physics of fast freezing $\mathrm{T}_{\mathrm{f}, \mathrm{FCS}}$ is unclear. The FCS concentration is much larger than the eutectic concentration (SI) and, therefore, the fast freezing $\mathrm{T}_{\mathrm{f}, \mathrm{FCS}}$ cannot produce the eutectic ice- $\left(\mathrm{NH}_{4}\right)_{2} \mathrm{SO}_{4}$ superlattice specified by a precise molecular percentage ratio between $\mathrm{H}_{2} \mathrm{O}$ and $\left(\mathrm{NH}_{4}\right)_{2} \mathrm{SO}_{4}$. Nonetheless, it forms somehow, because warming thermograms contain the eutectic melting peak (Figure 1a and Figure 1a in ref.36). However, it is stretched over a temperature region, whereas the eutectic superlattice should melt as a pure element at $\mathrm{T}_{\mathrm{E}}$. Hence, three questions arise: how does FCS freeze, how does the eutectic ice-( $\left(\mathrm{NH}_{4}\right)_{2} \mathrm{SO}_{4}$ superlattice form, and why is the eutectic melting peak stretched? Answers are given below.

The fast freezing of FCS. Cooling 5-48 wt\% $\left(\mathrm{NH}_{4}\right)_{2} \mathrm{SO}_{4}$ thermograms show that the shape of peaks $\mathrm{T}_{\mathrm{f}, \mathrm{ice}}$ and $\mathrm{T}_{\mathrm{f}, \mathrm{FCS}}$ is identical (Figure 1a and Figure 1a in ref.36). SV7, SV8 and SV10 demonstrate that the propagation speed of $\mathrm{T}_{\mathrm{f}, \mathrm{ice}}$-front and $\mathrm{T}_{\mathrm{f}, \mathrm{FCS}}{ }^{-}$ front is the same. These observations suggest that ice crystallization plays a major role at $\mathrm{T}_{\mathrm{f}, \mathrm{FCS}}$. The absence of an incline thermogram below $T_{f, F C S}$ (Figure $1 \mathbf{b}$ and Figure 6 in ref.41) indicates that all the water in FCS transforms to ice. The accompanying rapid increase of concentration to $100 \mathrm{wt} \%\left(\mathrm{NH}_{4}\right)_{2} \mathrm{SO}_{4}$ leads to a high nucleation rate. Since $\left(\mathrm{NH}_{4}\right)_{2} \mathrm{SO}_{4}$ crystallizes slowly (SV6-SV8), the high nucleation rate produces numerous $\left(\mathrm{NH}_{4}\right)_{2} \mathrm{SO}_{4}$ microcrystals. Indeed, these microcrystals are visible after the eutectic melting in the FCS bulges of hypoeutectic films (SV11-SV13). In eutectic and hypereutectic films, $\left(\mathrm{NH}_{4}\right)_{2} \mathrm{SO}_{4}$ microcrystals survive even above $273 \mathrm{~K}$ (SV14, $\mathrm{SV} 15)$. Note, frozen FCS is striped and consists of the irregular layers of ice and $\left(\mathrm{NH}_{4}\right)_{2} \mathrm{SO}_{4}$ microcrystals (images $5 \mathbf{a}$ and $5 \mathbf{b}$ ).

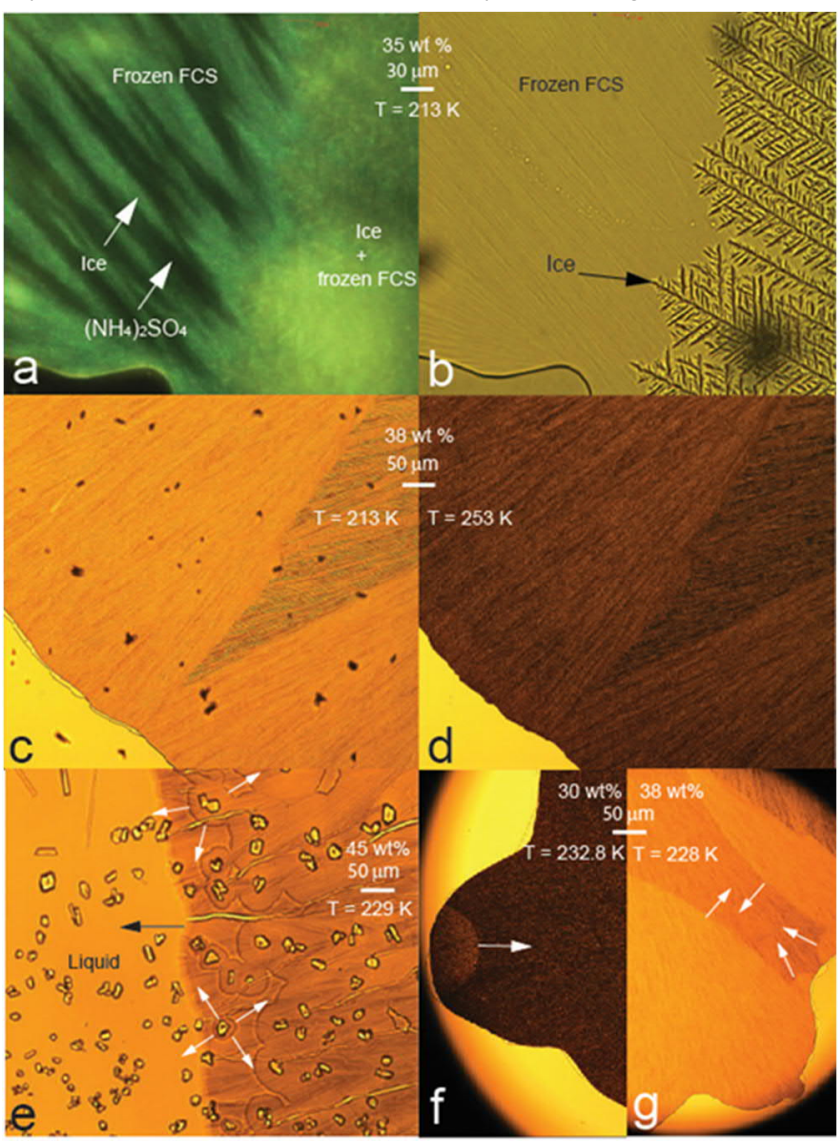

Figure 5. Images of frozen $\left(\mathrm{NH}_{4}\right)_{2} \mathrm{SO}_{4} / \mathrm{H}_{2} \mathrm{O}$ films. a, b, Images taken from the same region in the reflected and transmitted light modes show the striped structure of frozen FCS and ramified/dendritic IM. c, d, The darkening process during the warming of frozen solution. Note, in image d, ice crystals (black spots) have subli-

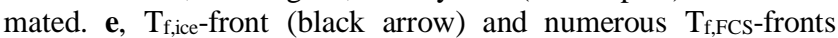
formed on/around $\left(\mathrm{NH}_{4}\right)_{2} \mathrm{SO}_{4}$ crystals (white arrows). $\mathbf{f}, \mathbf{g}, \mathrm{T}_{\mathrm{f}, \mathrm{FCS}-}$ front often starts at the edge of samples/films.

The formation of eutectic ice- $\left(\mathrm{NH}_{4}\right)_{2} \mathrm{SO}_{4}$ superlattice. All frozen 10-48 wt $\%\left(\mathrm{NH}_{4}\right)_{2} \mathrm{SO}_{4}$ films/samples darken as temperature increases (SV11-SV15, images 5c, 5d). At $\mathrm{T}_{\mathrm{E}}$, the dark structure abruptly collapses, indicating that it is the eutectic ice$\left(\mathrm{NH}_{4}\right)_{2} \mathrm{SO}_{4}$ superlattice. To our best knowledge, its structure is unknown. For alloys, four eutectic superlattice structures were identified: lamellar, rod-like, globular and acicular. ${ }^{44}$ Most likely, the striped structure of frozen FCS contain tiny regions of the lamellar eutectic ice-( $\left(\mathrm{NH}_{4}\right)_{2} \mathrm{SO}_{4}$ superlattice consisting of the alternative molecular layers of ice and $\left(\mathrm{NH}_{4}\right)_{2} \mathrm{SO}_{4}$. Upon warming, molecular diffusion increases, and the eutectic regions grow owing to the recrystallization of ice and $\left(\mathrm{NH}_{4}\right)_{2} \mathrm{SO}_{4}$ microcrystals. The large number and different orientation of the growing eutectic regions increase the sample optical density and this explains the darkening process. The recrystallization of the metastable ice/ $\left(\mathrm{NH}_{4}\right)_{2} \mathrm{SO}_{4}$ structure into the lamellar eutectic ice- $\left(\mathrm{NH}_{4}\right)_{2} \mathrm{SO}_{4}$ superlattice is a new three-phase reaction. ${ }^{45}$ 
SV10 and image 5e demonstrate that the fast freezing $\mathrm{T}_{\mathrm{f}, \mathrm{FCS}}$ begins spatially on/around $\left(\mathrm{NH}_{4}\right)_{2} \mathrm{SO}_{4}$ crystals after the $\mathrm{T}_{\mathrm{f} \text {,ice- }}$ front has passed them. It is obvious that the crystals do not induce pointwise ice nucleation (image $4 \mathbf{g}$ ), but spatial nucleation of the lamellar eutectic ice- $\left(\mathrm{NH}_{4}\right)_{2} \mathrm{SO}_{4}$ superlattice. Since ice crystallizes much faster than $\left(\mathrm{NH}_{4}\right)_{2} \mathrm{SO}_{4}$, this leads to the formation of metastable striped ice/( $\left(\mathrm{NH}_{4}\right)_{2} \mathrm{SO}_{4}$ structure discussed above. In the samples without $\left(\mathrm{NH}_{4}\right)_{2} \mathrm{SO}_{4}$ crystals, the fast freezing $T_{f, F C S}$ begins on crystals formed/nucleated within the highly-supersaturated FCS, often at the edge of samples where the concentration is larger due to water evaporation (images $5 \mathbf{f}$ and 5g).

Stretched eutectic melting. In frozen hypoeutectic samples, not all ice participates in the eutectic superlattice crystallization. In frozen eutectic and hypereutectic samples, due to the nonuniform IM/FCS morphology, there are regions in which part of the ice also does not enter the eutectic superlattice. Above $T_{E}$, the formed eutectic solution accelerates the melting of the remaining ice that makes the eutectic melting peak stretched (Figure 1a).

Finally, the degree of supercooling of micrometer-scaled $\left(\mathrm{NH}_{4}\right)_{2} \mathrm{SO}_{4} / \mathrm{H}_{2} \mathrm{O}$ drops is so large that $\mathrm{T}_{\mathrm{f}, \text { ice }}$ occurs near to, within or below the temperature region where $\mathrm{T}_{\mathrm{f}, \mathrm{FCS}}$ occurs (Figure 2 ). In this case the three freezing steps merge (Figure 1c), indicating that the freezing process of $\left(\mathrm{NH}_{4}\right)_{2} \mathrm{SO}_{4} / \mathrm{H}_{2} \mathrm{O}$ is size-dependent. $^{36}$

In summary, the presented DSC results and OCM videos explain the nature of the three-step freezing and three-phase reaction of deeply supercooled $\left(\mathrm{NH}_{4}\right)_{2} \mathrm{SO}_{4} / \mathrm{H}_{2} \mathrm{O}$. These results extend the $\left(\mathrm{NH}_{4}\right)_{2} \mathrm{SO}_{4} / \mathrm{H}_{2} \mathrm{O}$ phase diagram and provide a new insight into the physical chemistry of other deeply supercooled solutions, whose behavior is not predicted by the phase diagram. The proposed approach to estimate the FCS concentration (SI) makes it possible to use $\left(\mathrm{NH}_{4}\right)_{2} \mathrm{SO}_{4} / \mathrm{H}_{2} \mathrm{O}$ as a model for the theoretical simulation of FIPS, which is currently in its infancy. This work further demonstrates that instead of considering only ice nucleation, it is necessary to consider the entire freezing process (ice nucleation, FIPS, ice/FCS morphology) when studding and modeling the formation, development and properties of ice clouds. ${ }^{10}$

\section{ASSOCIATED CONTENT}

\section{Supporting Information.}

Supplementary Information and Supplementary Videos (15) are available in the online version of the paper.

\section{AUTHOR INFORMATION}

\section{Corresponding Author}

Anatoli Bogdan-Department of Chemistry and Institute for Atmospheric and Earth System Research/Physics, University of Helsinki, P.O. Box 64, FI-00014 Helsinki, Finland; orcid.org/00000001-7339-6673;

Email:anatoli.bogdan@helsinki.fi

\section{Funding Sources}

The author's family.

\section{Notes}

The author declares no competing financial interest.

\section{ACKNOWLEDGMENT}

This work is in memoriam M. Molina. The author thanks H. Bogdan, N. Hetemäki, L. Rontu and J. Löjdquist for useful discussion and M. Haaramo, S. Palmunen, Niko-Ville Koljonen, Markus Minkkinen and N. Jiganova for technical support. During this work, the author did not receive any financial support or grants from funding agencies in the public, commercial, or not-for-profit sectors. The author greatly appreciates the financial support of his family.

\section{REFERENCES}

1. Dos Santos-Neto, P.C.; Cuadro, F.; Barrera, N.; Crispo, M.; Menchaca, A. Embryo survival and birth rate after minimum volume vitrification or slow freezing of in vivo and in vitro produced ovine embryos. Cryobiology, 2017, 78, 8-14, DOI: 10.1016/j.cryobiol.2017.08.002

2. Pearce, R. S. Plant freezing and damage. Ann. Bot. 2001, 87, 417424, DOI:10.1006/ANBO.2000.1352

3. Boldt, J. Current results with slow freezing and vitrification of the human oocyte. Reprod Biomed Online, 2011, 23 (3), 314-322, DOI: 10.1016/j.rbmo.2010.11.019

4. Muto, T.; Harada, M.; Fukuhara, G.; Okada, T. Ice Confinement-Induced Solubilization and Aggregation of Cyanonaphthol Revealed by Fluorescence Spectroscopy and Lifetime Measurements. J. Phys. Chem. B 2020, 124 (18), 3734-3742, DOI: 10.1021/acs.jpcb.0c01451 5. Fujino, S.; Inagawa, A.; Harada, M.; Okada, T. Size-Tunable Micro/Nanofluidic Channels Fabricated by Freezing Aqueous Sucrose. ACS Omega 2019, 4 (8), 13570-13576, DOI: 10.1021/acsomega.9b01966 6. Moll, C.J.; Meister, K.; Versluis, J.; Bakker, H.J. Freezing of Aqueous Carboxylic Acid Solutions on Ice. J. Phys. Chem. B 2020, 124 (25) 5201-5208, DOI: 10.1021/acs.jpcb.9b10462

7. Rempel, A.W. Hydromechanical Processes in Freezing Soils. Vadose Zone Journal 2012; 11 (4): vzj2012.0045, DOI: 10.2136/vzj2012.0045

8. Barnes, P. R. F.; Wolff, E. W. Distribution of soluble impurities in cold glacial ice. J. Glaciol. 2004, 50, 311-324, DOI: 10.3189/172756504781829918

9. Thomas, D. N.; Kattner, G.; Engbrodt, R.; Giannelli, V. Dissolved organic matter in Antarctic sea ice. Ann. Glaciol. 2001, 33, 297-303, DOI: $10.3189 / 172756401781818338$

10. Bogdan, A. Ice clouds: Atmospheric ice nucleation concept versus the physical chemistry of freezing atmospheric drops J. Phys. Chem. A 2018, 122 (39), 3109-3116, DOI: 10.1021/acs.jpca.8b07926

11. Kawasaki, H.; Toshinori Shimanouchi, T.; Kimura. Y. Recent development of optimization of lyophilization process. Journal of Chemistry 2019, Article ID 9502856, 14 pages, DOI: 10.1155/2019/9502856 12. Bogdan, A., Molina, M. J., Tenhu, H., Bertel, E., Bogdan, N. \& Loerting, T. Visualization of freezing process in situ upon cooling and warming of aqueous solutions. Sci. Rep. 2014, 4, 7414, DOI: 10.1038/srep07414

13. Tang, X. C.; Pikal, M. J. Design of freeze-drying processes for pharmaceuticals: Practical advice. Pharm. Res. 2004, 21, 191-200, DOI: 10.1023/B:PHAM.0000016234.73023.75

.14. Levine, H. Amorphous food and pharmaceutical systems; RSC Publishing: Cambridge, U.K., 2002.

15. Petzold, G.; Aguilera, J. M. Ice morphology: Fundamentals and technological applications in foods. Food Biophysics 2009, 4, 378-396, DOI: $10.1007 / \mathrm{s} 11483-009-9136-5$

16. Flores-Ramirez, A.J.; Garcia-Coronado, P.; Grajales-Lagunes, A.; Garcia, R.G.; Archila, M.A.; Cabrera, M.A.R. Freeze-Concentrated Phase and State Transition Temperatures of Mixtures of Low and High Molecular Weight Cryoprotectants. Advances in Polymer Technology, 2019, Article ID 5341242, 1-11, DOI: 10.1155/2019/5341242

17. Basile, P.; Dadali, T.; Jacobson, J.; Hasslund, S.; Ulrich-Vinther, M.; Søballe, K.; Nishio, Y.; Drissi, M.H.; Langstein, H.N.; Mitten, D.J.; O'Keefe, R.J.; Schwarz, E.M.; Awad H.A. Freeze-dried tendon allografts as tissue engineering scaffolds for Gdf5 gene delivery. Mol. Ther. 2008, 16 (3), 466-473, DOI: 10.1038/sj.mt.6300395

18. John, M.; Suominen, M.; Sormunen, O-V.; Hasan, M.; Kurvinen, E.; Kujala, P.; Mikkola, A.; Louhi-Kultanen, M. Purity and mechanical 
strength of naturally frozen ice in wastewater basins. Water Research 2018, 145 (15) 418-428, DOI: 10.1016/j.watres.2018.08.063

19. Rich, A.; Mandri, Y.; Bendaoud, N.; Mangin, D.; Abderafi, S.; Bebon, C.; Semlali, N.; Klein, J.; Bounahmidi, T.; Bouhaouss, A.; Veesler, S. Freezing desalination of sea water in a static layer crystallizer. Desalin. Water Treat. 2010, 13 (1-3), 120-127, DOI: 10.5004/dwt.2010.983

20. Randall, D.G.; Zinn, C.; Lewis, A. E. Treatment of textile wastewaters using eutectic freeze crystallization. Water Sci. Technol. 2014, 70 (4), 736-741, DOI: 10.2166/wst.2014.289

21. Dong, J.; Hubel, A.; Bischof, J. C.; Aksan, A. Freezing-induced phase separation and spatial microheterogeneity in protein solutions. $J$. Phys. Chem. B. 2009, 113 (30), 10081-10087, DOI: $10.1021 / \mathrm{jp} 809710 \mathrm{~d}$

22. Roessl, U.; Leitgeb, S.; Nidetzky, B. Protein freeze concentration and micro-segregation analyzed in a temperature-controlled freeze container. Biotechnol Rep (Amst). 2015, Mar 26;6, 108-111, DOI: 10.1016/j.btre.2015.03.004

23. Cheng, J.; Soetjipto, C.; Hoffmann, M. R.; Colussi, A. J. Confocal fluorescence microscopy of the morphology and composition of interstitial fluids in freezing electrolyte solutions. J. Phys. Chem. Lett. 2009, 1 (1), 374-378, DOI: 10.1021/jz9000888

24. Petrenko, V. F.; Whitworth, R. W. Physics of ice; Oxford University Press, Oxford, 2006.

25. Kitada, K.; Suda, Y.; Takenaka, N. Acceleration and Reaction Mechanism of the N-Nitrosation Reaction of Dimethylamine with Nitrite in Ice. J. Phys. Chem. A 2017, 121 (29), 5383-5388, DOI: 10.1021/acs.jpca.7b03246

26. Takenaka, N.; Bandow, H. Chemical kinetics of reactions in the unfrozen solution of ice. J. Phys. Chem. A 2007, 111 (36), 8780-8786, DOI: $10.1021 / \mathrm{jp} 0738356$

27. Inagawa, A.; Ishikawa, T.; Kusunoki, T.; Ishizaka, S.; Harada, M.; Otsuka, T.; Okada, T. Viscosity of Freeze-Concentrated Solution Confined in Micro/Nanospace Surrounded by Ice. J. Phys. Chem. C 2017, 121 (22), 12321-12328, DOI: 10.1021/acs.jpcc.7b03792

28. Rohatgi, P.K.; Adams, C.M.Jr. Ice-brine dendritic aggregation formed on freezing of aqueous solutions. J. Glaciol. 1967, 6 (47), 663 679, DOI: $10.3189 / \mathrm{S} 0022143000019936$

29. Golden, K. M. Brine percolation and the transport properties of sea ice. Ann. Glaciol. 2001, 33, 28-36, DOI: $10.3189 / 172756401781818329$

30. Purdon, F. F.; Slater, V. W. Aqueous solution and the phase diagram; London: Edward Arnold \& Co., 1946.

31. http://www.chemguide.co.uk/physical/phaseeqia/saltsoln.html (accessed 2021-9-22)

32. https://academic.uprm.edu/pcaceres/Courses/MatEng/MSE7-2.pdf (accessed 2021-9-22).

\section{For Table of Contents Only}

The three-step freezing and eutectic melting of 40 wt $\%\left(\mathrm{NH}_{4}\right)_{2} \mathrm{SO}_{4}$

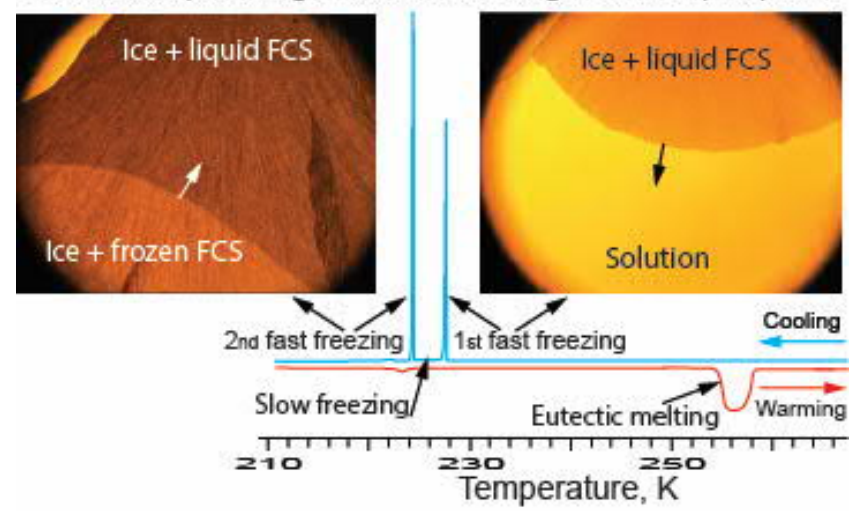

33. http://csmgeo.csm.jmu.edu/geollab/Fichter/IgnRx/BinryEu.html (accessed 2021-9-22).

34. Bogdan, A. Double freezing of $\left(\mathrm{NH}_{4}\right)_{2} \mathrm{SO}_{4} / \mathrm{H}_{2} \mathrm{O}$ droplets below the eutectic point and the crystallization of $\left(\mathrm{NH}_{4}\right)_{2} \mathrm{SO}_{4}$ to the ferroelectric phase. J. Phys. Chem. A 2010, 114 (37), 10135-10139, DOI: $10.1021 / \mathrm{jp} 105699 \mathrm{~s}$

35. Bogdan, A.; Molina, M. J.; Tenhu, H.; Loerting, T. Multiple glass transitions and freezing events of aqueous citric acid. J. Phys. Chem. A 2015, 119 (19), 4515-4523, DOI: 10.1021/jp510331h

36. Bogdan, A.; Molina, M. J.; Tenhu, H.; Mayer, E.; Bertel, E.; Loerting, T. Different freezing behavior of millimeter- and micrometerscaled $\left(\mathrm{NH}_{4}\right)_{2} \mathrm{SO}_{4} / \mathrm{H}_{2} \mathrm{O}$ droplets. J. Phys: Condens. Matter 2011, 23 , 035103(6pp), DOI: 10.1088/0953-8984/23/3/035103

37. Bogdan, A.; Molina, M.J.; Tenhu, H.; Loerting, T. Single freezing and triple melting of micrometre-scaled $\left(\mathrm{NH}_{4}\right)_{2} \mathrm{SO}_{4} / \mathrm{H}_{2} \mathrm{O}$ droplets. Phys. Chem. Chem. Phys. 2011, 13 (44), 19704-19706, DOI: $10.1039 / \mathrm{c} 1 \mathrm{cp} 21770 \mathrm{~d}$

38. Duong-Ly, K.C.; Gabelli, S.B. Salting out of proteins using ammonium sulfate precipitation. Methods Enzymol. 2014, 541, 85-94, DOI: 10.1016/B978-0-12-420119-4.00007-0

39. Zuberi, B.; Bertram, A.K.; Koop, T.; Molina, L. T.; Molina, M. J. Heterogeneous freezing of aqueous particles induced by crystallized $\left(\mathrm{NH}_{4}\right)_{2} \mathrm{SO}_{4}$, ice, and letovicite. J. Phys. Chem. A 2001, 105 (26), 64586464, DOI: 10.1021/jp010094e

40. Abbatt, J. P. D., Benz, S., Cziczo, D. J., Kanji, Z., Lohman, U. \& Mohler, O. Solid ammonium sulfate aerosols as ice nuclei: A pathway for cirrus cloud formation. Science 2006, 313, 1770-1773, DOI: 10.1126/science. 1129726

41. Bogdan, A.; Loerting, T. Impact of substrate, aging, and size on the two freezing events of $\left(\mathrm{NH}_{4}\right)_{2} \mathrm{SO}_{4} / \mathrm{H}_{2} \mathrm{O}$ droplets. J. Phys. Chem. C 2011, 115 (21), 10682-10693, DOI: 10.1021/jp2007396

42. Beyer, K. D.; Bothe, J. R.; Burrmann, N. Experimental determination of the $\mathrm{H}_{2} \mathrm{SO}_{4} /\left(\mathrm{NH}_{4}\right)_{2} \mathrm{SO}_{4} / \mathrm{H}_{2} \mathrm{O}$ phase diagram. J. Phys. Chem. A 2007, 111 (3), 479-494, DOI: 10.1021/jp0645465

43. Xu, J.; Imre, D.; McGraw, R.; Tang, I. Ammonium sulfate: Equilibrium and metastability phase diagrams from 40 to $-50{ }^{\circ} \mathrm{C}$. J. Phys. Chem. B 1998, 102 (38), 7462-7469, DOI:10.1021/JP981929X

44. Smith, W. F.; Hashemi, J. Foundations of materials science and engineering (4th ed.), McGraw-Hill, 2006.

45. http://www.engineeringarchives.com/les_matsci_threephasereactions.html (accessed 2021-9-22). 